\title{
Discursive Discrimination and Its Expressions ${ }^{1}$
}

\author{
KRISTINA BorÉUS
}

\begin{abstract}
The preservation and improvement of the human race is of course an important state interest. The existence of a large number of physically and psychologically inferior individuals is a burden to society in more than one respect.
\end{abstract}

The quotation might seem extreme, but is, unfortunately, not unique to the time and place of its origin: the Swedish parliament of $1933 .^{2}$ Groups of people, seen as inferior, are socially excluded, discriminated against, physically attacked, and persecuted in different societies at different times. Hostility of that kind may be mild or fierce, ranging from prejudiced attitudes with no material effects on the victims, to genocide. Such processes are anything from unpleasant to devastating for the victims. It might also be argued that they are harmful to others than the victims in the societies in which they take place.

In what follows, I will present some preliminary findings from a research project which has a certain aspect of discrimination, discursive discrimination, as its object of study. ${ }^{3}$ My research material consists of a corpus ${ }^{4}$ of texts from the Swedish public domain at three points in time: 1932/-33, 1970/-71, and 1994/-95. A few texts from the beginning of the present century are also included. The corpus consists of texts from Swedish encyclopaedias, texts from the parliament, election propaganda, and a small number of newspaper articles and television programmes. I make in-depth textual analysis of how people categorised as deaf, as intellectually handicapped, as prostitutes, and as immigrants

Dept. of Political Science, Stockholm University, SE-10691 Stockholm,kristina.boreus@statsvet. su.se have fared in the Swedish public discourse at these different points in time.

The main objectives of the study are to develop better ways of analysing discursive discrimination in general and to add to our knowledge about the discursive treatment of the mentioned groups.

In this article, I will explain what I mean by 'discursive discrimination' and by another central analytical concept used in the study - 'othering' and explain how discursive discrimination and othering might be expressed in texts and discourse. I will also present some results of the analysis of the part of the corpus which treats the discourse on people called 'deaf and dumb' ('dövstumma')5 in 1932-33.

\section{Othering}

The concept of the Other is frequently used in contemporary literature, but often without being properly defined. I use an understanding of 'the Other' partly based on de Beauvoir (1997/1949) and on Todorov (1999). The term used in this study is 'othering'. By that I mean that a mental distance is created between 'us' and 'them'. The less othering, the more identification with the Others and the more similarity is perceived. The more othering, the larger is the rapprochement and the more important do the differences between 'us' and 'them' appear. Although othering is probably very important in processes of discursive discrimination, it is not necessarily discriminatory. Othering does not in itself imply a negative stance towards the Other. An interesting example of this is exoticism. The other is seen as strange but beautiful (Riggins 1997:5). Here the Other, perhaps the 'exotic' one outside the 'modern' world is perceived as different indeed, but in a good and interesting way, per- 
haps as superior to 'us'. All sorts of heroes might be othered: 'they' embody all the good traits wanting in ourselves which is exactly what makes 'them' different from 'us'.

I see it as important to make this distinction between the concepts of discrimination and of othering. Discrimination is hostile and pejorative. It need not happen in societies and it can be fought. But othering might be unavoidable: probably it is part of the human condition to categorise other humans and to find and ponder over differences between people. Unless the analytical distinction is made, it is not possible to research the important question of when the making of distinctions and the perception of differences become dangerous for the Others.

Othering might be done in several ways. I exemplify two here. The first regards how the Others are referred to, the second how they are described.

Different ways of referring to a category might be taken to reflect, as well as create, more or less of a distance between 'us' and 'them'. The most othering effect seems to appear when a category is referred to by a noun or an adjective used in a noun-like way. This indicates that the category is set in thought and language, which, in its turn, indicates that the characteristics of people which are the basis of the categorisation are seen as important enough to be the basis of a fairly permanent categorisation. Since it is exactly those characteristics which make the category different from 'us', this type of reference indicates, and probably helps to maintain, a quite strong othering. An example of this is that presently in Swedish discourse, 'immigrant' ('invandrare'), is a commonly used noun, which refers to a certain category, albeit with fuzzy borders.

Not only nouns, but also adjectives, are used as set category names in Swedish. The adjectives can then be used in a 'noun-like' manner. An example from the corpus is the use of the adjective 'mentally deficient', 'sinnesslö'. In such a use, case-inflection is added directly to the adjective (which is the case with adjectives in Swedish when there is no noun to inflect (Andersson 1994:34). In the following example the 's' after 'sinnesslöa' is the added case inflection:

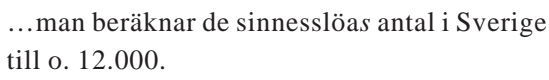

...the number of mentally deficient in Sweden is estimated to be appr. 12,000.

(Svensk Uppslagsbok, 1935, 'Sinnesslöhet'; my italic) ${ }^{6}$
The noun (that would be 'personer' ('persons')) is regularly left out, like in the following quote:

Sinnesslöanstalt avser vård och uppfostran av sinnesslöa.

Asylum for the mentally deficient means care
and training of mentally deficient (persons).

(Nordisk Familjebok 1932, 'Sinnesslöanstalt'; my italics)

These ways of treating adjectives like nouns are perfectly normal in Swedish, and seem to indicate that the categories are more conventionalised than when expressions like 'mentally deficient people' or 'people suffering from mental deficiency' are used. Not all adjectives can be used in this nounlike way: if someone is tall it takes very special contexts to leave out the noun since TALL PERSON is not a conventionalised category. It seems normal to say 'Jag känner en döv', 'I know a deaf (person)', but not 'Jag känner en lång', 'I know a tall (person).'

A slightly less othering way of referring to categories seems to be by set expressions, ways of referring to a group which are conventionalised in a language but which are neither single nouns nor adjectives treated as nouns. When this way of referring to a category is used it seems to leave more scope for other categorisations of the same person. More flexibility in the categorisation means that the difference from 'us' is less emphasised. An example from the corpus is the expression 'people with intellectual handicaps' ('personer med begåvningshandikapp') which was a frequently used way of referring to a certain category in $1994-95$.

The least othering way of referring to a category seems to be by a description, which is particular to the context and not a set expression. An example is the use of wordings like 'a man who immigrated to Sweden 12 years ago'. The use of that expression, within the present discourse, probably has the effect that most readers place the person in the category IMMIGRANT. Yet, the expression makes it clear that the person in question has done other things than moved countries in his life and might be categorised in other ways too.

Othering descriptions, like in the quote below, also appear in the corpus. 'They' are said to be different in many ways. The intellectually handicapped are described as different, not only intellectually, but also, for example, in bodily appearance:

Down's syndrome (...) The degree of mental retardation is moderate to severe. Bodily development is also affected. The appearance is 
peculiar. The forehead and the back of the head are flattened. Eye sockets are smaller than normal, and the corners of the eyes are drawn upward, 'the eyes are slanted'. The inner corners of the eyes have a wrinkle of the skin (epicantus). The tongue is large and often protrudes between the lips; the neck is short and thick. (...) In a person with Down's syndrome, the brain only reaches $75 \%$ of the normal weight.

(Nationalencyclopedin 1991, 'Downs syndrom')

The description has a strong othering tone. What is different from the norm is pointed out, in great detail. ${ }^{7}$ The norm is not stated, but it is obvious that a 'large' tongue is large in comparison with the tongue of a person without Down's syndrome. The information is obviously not given because it says something important about the life of a person with Down's syndrome. Whatever the motive behind putting the description in the encyclopaedia, the most obvious effect is that people with Down's syndrome appear as different from 'us' who have eye sockets of 'normal' size and non-thick necks. It is even stated that the persons in question have a peculiar appearance ("särpräglat utseende").

\section{Discursive Discrimination}

'Discrimination' in this study is understood as unfavourable treatment of members of a group on account of their membership of that group. Discrimination is a violation of the ideal of a fair and equal society, a minimum requirement of which is that groups of people are not directly treated as inferior to the rest of the population. Discursive discrimination appears when such treatment takes linguistic expressions (and not, for instance, the expression of physical violence). A group 'membership' might be alleged: the discriminating part might find similarities between people that these persons do not themselves consider as similarities, or not as similarities important enough to make them belong to the same group. Thus, people who have once immigrated to a country, or even their children who have not immigrated, might be lumped together as 'foreigners' or 'immigrants' even though they do not see themselves as belonging to the same group.

Unfavourable treatment may take a multitude of forms in text and discourse. The main types of discursive discrimination I have found I call (1) exclusion, (2) negative other-presentation, (3) discriminatory objectification, and (4) arguing for unfavourable treatment of group members.
(1) Exclusion, when human beings are deliberately excluded from a group, locked out, being deprived of goods of various types, tends to be generally seen as unfavourable treatment. Discursive exclusion might take several different forms. One form I call making invisible. A group of people can be made invisible in discourse in different ways. One way is by under representation: films never cast lesbian or gay love stories, people with visible handicaps are not shown on TV, women, children and the elderly occur much more seldom than in the real population and so on. According to several media researchers, groups which are assigned a low social value are under represented in media and other public discourse. This, in turn, is thought to further undermine the position of these groups in society. Tuchman (1978) uses the term 'symbolic annihilation' to cover both the under representation of women found in the television of several countries and the playing down of women's importance by trivialising them. At the very least, this type of making invisible implies that the invisible are considered unimportant, uninteresting or irrelevant (Strand 1989:80; von Feilitzen 1989:57).

Another form of making invisible is achieved solely by the use of certain words. Linguistic exclusion can take different forms. A common one is when a group is made invisible by being included into a generic form which only names another group. An often stated example is how women are said to be included in categories named 'MANkind' or 'men' or referred to by the so called generic 'he'. While, in a logical sense, it is clear that women are part of mankind, this is still a case of exclusion. The very expressions tell us that the typical, normal, or relevant human is a man. Not only might the reference to a certain group be excluded, but also its experiences. Fowler (1991:96) exemplifies with the words for heterosexual intercourse: the word 'penetrate', which is that of male experience, is frequently used in descriptions of intercourse while the word 'enclose' is not.

Not the least important form of exclusion is what might be called the exclusion of voices. Members of a certain group are excluded from taking part in a discourse in which issues of importance for them as a group are discussed. An example from my corpus is the fact that no individuals classified as 'mentally deficient' were heard in the discussion that went on in 1933 in Sweden on a sterilisation law, despite one of the main target groups being just 'the mentally deficient'. Such exclusion is to be seen as unfavourable treatment since people themselves are normally thought to be the best 
interpreters of their own interest. This entails that they should have a say in matters of importance to them.

(2) The term 'negative other-presentation' comes from van Dijk (1993 and other works). It refers to the ways that an in-group can express that an out-group is inferior. This can be done in various ways, such as, for instance, by the use of derogative labelling or negatively evaluative descriptions, and by using derogative metaphors. A corpus example of derogative labelling is the use of the term 'idiot' ('idiot') for a certain category of people with intellectual handicaps in the 1930s and later on. This was the official term used but, according to contemporary dictionaries, the word had a dual meaning: it was also used as an insult. The use of a word rooted in language use as an insult to officially refer to a group of people must be seen as derogatory.

(3) Discriminatory objectification takes place when a group of people tend to be discursively treated only as the objects of some purposes of other agents. The sterilisation debate may serve as an example once more. Not only were the voices of the main target group for the sterilisation policy excluded. They were also treated only as objects for the alleged purpose of the policy, racial improvement. Hardly any references were made to the interests of the people discussed. When in an entire discourse a group is only, or almost only, treated as the objects of the actions of others and not as having its own needs and interests, this is unfavourable treatment.

(4) Arguing for unfavourable treatment of group members occurs when some negative treatment other than purely linguistic, particular to the group in question, is argued for. This aspect of discursive discrimination is important because it has such a strong connection with discrimination taking place outside discourse. A corpus example is when the xenophobic party Ny Demokrati, New Democracy, put out propaganda material for the 1994 Swedish general election with the slogan: "Deport foreign criminals who have committed serious crimes." It was to be understood that "foreign criminals" included Swedish residents who were not citizens (if not also immigrants who had citizenship). The argument is discriminatory because it singles out a certain group of criminals to be treated in a (more) unfavourable way than the rest: what New Democracy means is that these persons should first be punished in Sweden and then deported, while 'Swedish' criminals should be punished in Sweden but not deported.
The four ways of discriminating discursively presented here are likely to interact in real situations of discrimination. Negative other-presentation often works as a rationale for exclusion, treating others merrily as objects, and proposing nonlinguistic forms of unfavourable treatment. Discursive discrimination is normally part of a larger pattern of discrimination in society.

A brief example will show how othering, exclusion, and negative other-presentation have been studied in the corpus. The example regards the discourse on people called 'deaf and dumb' as represented in the part of the corpus from around the years 1932 and 1933.

Othered, Excluded, and Derogatively Labelled: 'The Deaf and Dumb' in 1932-33

All people born deaf or who had become deaf in early childhood were considered to be mute and called 'deaf and dumb' ('dövstumma'). During the $20^{\text {th }}$ century there was a gradual development of the schooling system for this group. The schooling system for deaf children in 1932-33 fell under what was called schooling for 'abnormal children'. At the time, the oral method of teaching deaf children was prevailing. The use of sign-language was discouraged. The education was supposed to be carried out in spoken Swedish and the children were trained in lip-reading and speaking (Pärsson 1997).

Othering was clearly taking place. DEAF AND DUMB was a set category in the discourse and 'deaf and dumb' was an adjective which was regularly used in the noun-like manner described above. Like with the adjective 'mentally deficient' this one often took case inflection:

De dövstummas antal har under de sista årtiondena avtagit

The number of the deaf and dumb has decreased during the last decades

(Nordisk Familjebok 1927, 'Dövstumhet'; my italic)

The noun (which could have been 'children', 'persons', or 'pupils' in the quote below) is regularly left out:

Talmetod, en vid undervisning av dövstumma använd undervisningsmetod...

Oral method, a method used in the teaching of deaf and dumb (children etc.)...

(Svensk Uppslagsbok 1936, 'Talmetod'; my italics) 
The term 'deaf and dumb' is othering in yet another way. Congenital deafness or deafness obtained in early childhood was, as stated above, said to lead to deaf-muteness (Svensk Uppslagsbok 1931; Nordisk Familjebok 1927). But what did 'dumb' really mean?

The hearing child learns to understand spoken language... The child born deaf can learn neither to understand the speech of others, nor to speak itself in that way and becomes dumb. Also the child who becomes deaf at the age of 4 or 5 , even later, will soon forget what it has learned of language and becomes dumb too.

\section{(Nordisk Familjebok 1927, 'Dövstumhet')}

'Dumb' obviously did not refer to a purely physiological state like a fault in the organs of speech but to the fact that a deaf child does not express itself in oral language. The 'dumbness', however, did not exclude the possibility of deaf people learning to speak, albeit defectively:

In the deaf-and-dumb school most deaf-mute children come to learn to understand the speech of other people by so called lip-reading (...) and also to speak themselves by making out the movements of their own organs of speech by their sense of touch. Lip-reading, however, is always more or less faulty and speech very monotonous and difficult to understand.

(Nordisk Familjebok 1927, 'Dövstumhet')

The meaning of 'dumb' in 'deaf and dumb', thus, seems to be that a deaf child does not spontaneously learn to speak orally and/or that s/he only learns a 'defective' way of speaking. The term 'dumb' ('stum') was used, despite the fact that the word in normal language use referred to a complete disability to speak. There are two possible interpretations of this apparent paradox. Either the word 'stum' is a remnant from earlier times when it was believed that people who became deaf early in life were both deaf and (truly) mute, or the label is the result of a very othering strategy. The othering attitude towards a group is strengthened by the recurrent mentioning of differences between 'us' and 'them', however unimportant the differences might be. In this case, what seems to happen is that an existing difference (the easiness with which one learns to speak with one's voice) is exaggerated: a person who, because of deafness, has a larger difficulty in speaking is called 'dumb' despite the fact that the word in question denotes something that deaf people are known not to be. Whatever the mo- tivation for this labelling, the use of it would have had an othering effect. The labelling also has to do with the non-recognition of sign-language as a proper language. If the difference appreciated were between 'us' who use a spoken language and 'them' who use a sign language this would surely have been felt as less of a difference than that between 'us' who can speak and 'them' who are unable to.

In this part of the corpus, I found not only othering, but also expressions of exclusion and negative other-presentation. The corpus points to the conclusion that the voices of deaf people were excluded. ${ }^{8}$ In the parliamentary material, several issues which ought to be of considerable interest for people counted as belonging to this category, are discussed: the sum of state grants to the education of the 'deaf and dumb' and to their organisations and journals and a major reform intended to nationalise the entire education of the 'deaf and dumb'. There is no reference to the opinions of deaf people as a group on these issues. It is especially noteworthy that when the demand for nationalisation of this type of schooling was raised, the only argument put forward was economical:

\footnotetext{
Regarding this issue, however, on several occasions, a strong opinion has emerged aiming at the state's ... taking over the totality of this type of education of the abnormal. (...) This is, generally, not about putting an increased burden on the taxpayers of the country, in which case one could possibly have understood the hesitation in a time of crisis like the present - the point is rather to free the county councils, of which many carry a heavy tax burden, from a load which exists for a purpose which would seem to be considered a purpose of the state, the costs of which should ideally be equally distributed over all parts of the country. ${ }^{9}$
}

The corpus only contains a fraction of the discussion on this issue, which went on for years before the nationalisation was finally decided on in 1937. Other types of arguments were put forward during that discussion. But in the year analysed, which was one of economic crises, only the economic arguments were used in the parliamentary part of the discourse. The whole political discourse was affected by the economic crises, but this would not seem to make a reference to the interests of the most affected less relevant.

The relevant material is fairly limited in my corpus, but other research supports the conclusion that deaf people's 'voices' were excluded. Höglund (1993) finds that the organisations for deaf people 
were dominated by hearing experts, as were their journals at the time. Since these organisations and journals were, per definition, dealing with issues of importance for deaf people, this could be seen as a clear example of the exclusion of voices.

Furthermore, there is negative other-presentation in the corpus. In comparison to the very explicit negative other-presentation of the group labelled 'mentally deficient' at the time these expressions are not very strong. What was derogatory was the use of the words 'abnormal', 'abnorm', and 'defective', 'defekt', in labelling deaf people. As was stated above, the 'deaf and dumb' was one of the subgroups of people called 'abnormal'. In Svensk Uppslagsbok (1929) the word 'abnorm' is defined as "...that deviates from the law-like or common; unnatural; in want of some abilities, mentally deficient, sickly in body or mind". That the existence of the category ABNORMAL PERSON is not restricted to these texts is shown by the appearance of the words 'abnormundervisning' ('education for abnormal children') and 'abnormskola', ('school for abnormal children') as separate entries in Svensk Uppslagsbok (1929). The expression also occurs in the parliamentary material. From the second half of the $19^{\text {th }}$ century, deaf children together

\section{Notes}

1. I want to thank Pingo Kåreholt and Katharina Tollin for comments on this text.

2. Report no. 12, 1933, of the second standing committee on laws regarding a submitted bill on the development of a new proposal for a sterilisation law. Here, the committee cites approvingly what it has stated in a report from 1922 on the same issue.

3. The research is not completed. I am presently writing a book that reports the study, but am also still working with both the corpus analyses and with the development of the theoretical framework.

4. 'Corpus' is a term mainly used within linguistics, referring to a collection of linguistic data, often compiled as a number of written texts.

5. In this text, the mentioning of words and terms are indicated by single inverted commas, Swedish words are in italics, categories of language and thought are referred to in SMALL CAPITALS, and a star marks a linguistic form which is felt to be incorrect in normal language use. with other groups were called 'abnormal' or 'defective' children (Förhammar 1991:22).

The use of these words works not only as a handy way of sorting the pupils for the schooling system. It implies at the very least that something is found wanting when compared to what is considered normal and natural, not only in the sense of most common. So the use of the label 'abnormal' for people who were deaf from childhood was a demeaning label.

\section{Summary}

In this article I have sketched ways of analysing othering and discrimination in discourse. I have showed how this has been done in a corpus containing texts discussing people categorised as 'deaf and dumb' in the early 1930s. This group was othered in the discourse, their voices were excluded and they were derogatively labelled.

A more systematic understanding of discursive discrimination would involve a better grasp of when othering is connected to discursive discrimination and how discursive discrimination is just one aspect of wider patterns of discrimination in societies. By using the tools presented above or other analytical tools in systematic ways on existing discourse in society, we might hope to gain such understanding.

6. The encyclopaedias used for the corpus collection of the years around 1932-33 were Svensk Uppslagsbok ("The Swedish Encyclopaedia") in 30 volumes issued between 1929 and 1937 and Nordisk Familjebok ("The Nordic Encyclopaedia for the Family") in 23 volumes issued between 1923 and 1937. A quote is also included in this article from Nationalencyklopedin ("The National Encyclopaedia") in 20 volumes issued between 1989 and 1996. All translations from the corpus are mine.

7. One of the other encyclopaedias in the corpus from the last period, Bra Böckers Lexikon 2000 (1996), gives an equally detailed description of how people with Down's syndrome look different, including the information that they have "a large space between the first and second toe".

8. The use of the metaphor of voices in regard to people who preferably express themselves with the help of signs is really a case of linguistic exclusion in itself: the natural way of communication for a minority of people is excluded.

9. Second Chamber bill no. 325, 1932. 


\section{References}

Andersson, Erik (1994) Grammatik från grunden. Uppsala: Hallgren \& Fallgren.

de Beauvoir, Simone (1997/1949) The Second Sex. London: Vintage.

Fowler, Roger (1991) Language in the News: Discourse and Ideology in the Press. London; New York: Routledge.

Förhammar, Staffan (1991) Från tärande till närande: Handikapputbildningens bakgrund och socialpolitiska funktion i 1800-talets Sverige. Stockholm: Almqvist \& Wiksell International.

Höglund, Birgitta (1993) Från visa till egna - en sociologisk studie om döv-och hörselskadeföreningarnas representantskap. Lund: Dept. of Sociology, Lund University Research Program in Medical Sociology.

Pärsson, Anita (1997) Dövas utbildning i Sverige 1889. 1971. En skola för ett språk och ett praktiskt yrke. Gothenburg: Dept. of History, Gothenburg University.

Riggins, Stephen Harold (1997) "The Rhetoric of Othering", in Riggins, Stephen Harold (ed.) The Language and Politics of Exclusion: Others in Discourse. Thousand Oaks; London; New Delhi: SAGE, pp. 1-30.
Strand, Hans (1989) "Nationalitet i svensk TV", in Nowak, Kjell, Strand, Hans, Andrén, Gunnar, Ross, Sven \& von Feilitzen, Cecilia (eds.) Folket i TV. Demografi och social struktur i televisionens innehåll Stockholm: Centrum för masskommunikationsforskning, Stockholm University, pp. 79-106.

Todorov, Tzvetan (1999) The Conquest of America: The question of the Other. Norman: University of Oklahoma Press.

Tuchman, Gaye (1978) "Introduction: The Symbolic Annihilation of Women by the Mass Media", in Tuchman, Gaye, Kaplan Daniels, Arlene \& Benét, James (eds.) Hearth and Home: Images of Women in the Mass Media. New York: Oxford University Press, pp. 3-38.

van Dijk, Teun A. (1993) Elite Discourse and Racism. Newbury Park; London; New Delhi: SAGE.

von Feilitzen, Cecilia (1989) "Barn, ungdomar, vuxna och äldre i TV”, in Nowak, Kjell, Strand, Hans, Andrén, Gunnar, Ross, Sven \& von Feilitzen, Cecilia (eds.) Folket i TV. Demografi och social struktur i televisionens innehåll. Stockholm: Centrum för masskommunikationsforskning, Stockholm University, pp. 27-57. 